\title{
Penerapan Project Based Learning untuk Meningkatkan Kemampuan Guru-Guru Sekolah Dasar Sidoarjo dalam Menulis Kreatif Cerita Anak
}

\author{
Ari Setyorini' $^{1}$, Masulah $^{2}$ \\ ${ }^{1,2}$ FKIP, Universitas Muhammadiyah Surabaya \\ Email: arisetyorini@fkip.um-surabaya.ac.id ${ }^{1}$, mmasulah@gmail.com²
}

\begin{abstract}
ABSTRAK
Pengabdian masyarakat ini bertujuan melatih guru-guru sekolah dasar untuk menulis kreatif sastra anak. Pelatihan ini didesain sejalan dengan program gerakan literasi nasional, yang salah satunya adalah program literasi sastra, di tingkat sekolah dasar. Pengabdian masyrakat ini bermitra dengan lima sekolah dasar di bawah pengelolaan Muhammadiyah Sidoarjo. Setiap sekolah mengirim dua guru perwakilan mereka untuk mengikuti pelatihan menulis kreatif yang dilaksanakan sejak Juli hingga September 2019. Kegiatan ini menggunakan metode Project Based Learning di mana guru dilibatkan untuk membuat proyek penulisan karya sastra anak. Proses pelatihan mengimplementasikan blended learning yang terdiri dari 16 jam workshop penulisan kreatif secara luring dan 32 jam sesi pendampingan yang dilakukan secara daring. Sesi luring dilakukan untuk membangun pengetahuan dasar peserta mengenai penulisan kreatif dan sastra anak. Sedangkan sesi online memfasilitasi peserta untuk mengirimkan dan mengkonsultasikan draf cerita mereka pada tim fasilitator pengabdian, yang kemudian mendapatkan umpan balik untuk revisi. Menggunakan penilaian mastery learning, sebanyak 90\% (yakni 9 dari 10 peserta) berhasil menuntaskan proyek penulisan cerita anak. Lebih lanjut, para peserta menyatakan bahwa kegiatan ini memberikan manfaat bagi mereka, mengenalkan mereka akan pengetahuan literasi sastra dan meningkatkan kemampuan menulis sastra anak khususnya dalam bentuk cerita gambar dan cerita pendek.
\end{abstract}

Kata Kunci: guru sekolah dasar; penulisan kreatif sastra anak; project based learning.

\section{ABSTRACT}

This community service aims to enhance elementary school teachers' literary literacy skills through children literature creative writing project. The training project designed was in line with the need of the inclusion of literary literacy in formal education particularly in primary educational level. The program was conducted by partnering with five elementaryschools under the management of Muhammadiyah Organizationin Sidoarjo. Each school registered their representative teachers to join the creative writing program which was held fromJuly until September 2019. The activity employed Project Based Learning in which the teachers were involved in children literature writing project. The training procedure was designed by implementing blended learning consisting 16-hour offline creative writing workshop and 32-hour online coaching session. The offline sessions were conducted to build the teachers' basic knowledge on creative writing and children literature. The online coaching sessions facilitated the participants to consult their drafts and revise them based on the facilitator's feedback. Measured by mastery learning assessment, $90 \%$ of participants (9 out of 10 participants) were successfully accomplished the writing project. For more, the participants agreed that this program was beneficial for them to enhance their knowledge on literary literacy and their writing ability to create children literary works like picture book and short story.

Keywords: children literature creative writing; project based learning; teacher of elementary school. 
PENDAHULUAN

Literasi secara sederhana dipahami sebagai kemampuan untuk membaca dan menulis. Tahap awal dari literasi adalah kemelek aksaraan, maksudnya adalah melek abjad dan mampu membaca rangkaian abjad. Setelah melek baca tulis, fokus literasi adalah lebih pada kemampuan seseorang untuk menyerap informasi saat melakukan kegiatan atau aktivitas membaca dan menulis.

Sedangkan menurut UNESCO (Antoro, Billy. 2017), literasi adalah seperangkat keterampilan kognitif dalam membaca dan menulis. UNESCO mencatat bahwa pemahaman seseorang akan literasi dipengaruhi oleh kompetensi bidang akademik, konteks nasional, institusi, nila-nilai budaya serta pengalaman. Selain itu, kemampuan ini merupakan kunci untuk siswa dalam menghadapi tantangan abad 21 di mana kanal informasi terbuka luas. Akibatnya siswa harus mampu memilah dan mengola informasi secara kritis.

Sayangnya, urgensi literasi dalam dunia pendidikan di negara kita tidak sejalan dengan kondisi nyata di lapangan. Hasil penelitian Programme for International Student Assessment (PISA) menyebut, budaya literasi masyarakat Indonesia pada 2012 terburuk kedua dari 65 negara yang diteliti di dunia. Indonesia menempati urutan ke 64 dari 65 negara tersebut. Pada penelitian yang sama, PISA juga menempatkan posisi membaca siswa Indonesia di urutan ke 57 dari 65 negara yang diteliti. PISA menyebutkan, tak ada satu siswa pun di Indonesia yang meraih nilai literasi ditingkat kelima, hanya 0,4 persen siswa yang memiliki kemampuan literasi tingkat empat. Penelitian PISA selanjutnya di tahun 2015 menempatkan Indonesia pada posisi 62 dari 72 negara dengan rata-rata skor 395, meskipun meningkat akan tetapi tidak menunjukkan peningkatan yang signifikan. (Antoro, Billy. 2017)

Muhajir Effendy (2019) saat menghadiri acara bulan Bahasa menyatakan bahwa salah satu ciri bangsa yang maju adalah bangsa kuat dan kokoh literasinya Karenanya Gerakan Literasi Nasional (GLN) menjadi salah satu program pemerintah yang gencar dilakukan akhir-akhir ini di sekolah-sekolah. Gerakan ini mewajibkan siswa untuk membaca karya sastra selama 15 menit sebelum pelajaran dimulai dan kemudian siswa diminta untuk mengapresiasi karya tersebut Membaca sastra ini dinilai menjadi salah satu cara efektif untuk meningkatkan minat baca dan literasi siswa.

Namun pelaksanaan di lapangan acapkali menemui hambatan, khususnya terkait dengan kemampuan literasi guru sebagai fasilitator GLN di sekolah. Hasil dari pengamatan awal terhadap pelaksanaan GLN di lapangan di sekolah dasar di Sidorajo oleh tim pengabdian masyarakat diketahui bahwa masih terdapat guru tidak ikut membaca atau melakukan kegiatan 
lain ketika kegiatan GLN tersebut dilakukan. Hal ini menjadi contoh yang kurang baik bagi siswa karena guru tidak menunjukkan semangat literasi itu sendiri. Hal ini dapat dicegah jika guru mengetahui pentingnya literasi bagi anak yang nampak tidak hanya melalui ucapan namun juga tercermin secara langsung melalui tindakan.

Selain itu, dari diskusi bersama dengan guru-guru sekolah dasar, diperoleh informasi bahwa pengetahuan guru akan literasi sastra masih kurang, sehingga guru kurang optimal ketika memberikan penjelasan pada siswanya mengenai apa sastra anak dan bagaimana siswa harus mengapresiasi sastra anak. Persoalan-persoalan ini yang mendasari dilakukannya pengabdian masyarakat ini oleh tim dari Universitas Muhammadiyah Surabaya.

\section{METODE PENELITIAN}

Tim pengabdian masyarakat mengadakan diskusi dengan Majlis Dikdasmen Muhammadiyah

Pimpinan Daerah Sidorajo untuk memilih mitra berdasar keterwakilan lokasi sekolah. Lima Sekolah Dasar Muhammadiyah (SDM) kemudian terpilih, yakni wilayah Sidoarjo Barat diwakili oleh SDM Balungbendo, Sidoarjo Pusat dipilih SDM 1 Pucanganom, Sidoarjo bagian utara diwakili SDM 3 Waru, Sidoarjo bagian timur diwakili SDM 1 Sedati, dan Sidoarjo bagian selatan diwakili olehMIM Pucangsewu Tanggulangin. Masing-masing sekolah dipilih 2 guru untuk menjadi wakil untuk mengikuti pelatihan.

Pelatihan ini didesain menggunakan Project Based Learning (PBL). PBL adalah model yang sesuai untuk diaplikasikan karena model pembelajaran ini menekankan pada pemecahan masalah dengan mengaplikasikan pengetahuan yang dimiliki melalui pengerjaan proyek guna menghasilkan produk yang autentik. (Boss dan Kraus dalam Abidin, 2007: 167) PBL memiliki tujuh elemen utama dalam mendesain proyek pembelajaran, yakni: 1). penyelesaian terhadap permasalahan utama, 2). penyelesaian masalah yang berkelanjutan, 3). autentisitas proyek, 4). berfokus pada pilihan dan suara peserta, 5). dapat merefleksikan proses pembelajaran, 6). mampu merevisi berdasarkan feedback yang diberikan, dan 7). proyek didisplay secara umum.

Pada kegiatan ini guru menyelesaikan proyek penulisan cerita anak yang disusun berdasarkan kearifan lokal budaya setempat dengan memfasilitasi ketujuh tujuan utama dari PBL tersebut.

Sedangkan untuk metode kegiatan dilakukan Blended Learning yang membagi kegiatan menjadi dua jenis kegiatan utama, yakni: 1). 16 jam workshop penulisan kreatif secara luring, yang berisi pengetahuan dasar peserta mengenai penulisan kreatif dan sastra anak, dan 2). 32 jam sesi pendampingan yang dilakukan secara daring melalui email dan whatsapp untuk memfasilitasi peserta mengirimkan dan mengkonsultasikan draf cerita mereka pada tim fasilitator 
pengabdian, yang kemudian mendapatkan umpan balik untuk revisi.

Ketercapaian proyek akan diukur menggunakan penilaian Mastery Learning dengan menentukan skala ketuntasan belajar di atas $75 \%$ dari total peserta. Sehingga, kegiatan ini dinilai berhasil jika peserta yang dapat menyelesaikan proyek menulis adalah $75 \%$ dari total peserta (atau 8 dari 10 guru berhasil menulis sastra anak).

\section{HASIL DAN PEMBAHASAN}

Guna menjawab persoalan yang muncul, tim kemudian menyusun beberapa solusi, yakni: 1). Guru perlu diberikan pelatihan tentang literasi sastra yang dimulai dengan penjelasan akan pengetahuan dasar literasi dan sastra anak, 2). Guru dilatih menulis sastra anak, karena dengan menulis sendiri cerita anak, pengetahuan yang didapat akan teraplikasikan secara nyata. Dengan demikian, diharapkan implementasi literasi akan terwujud melalui tindakan. Selain itu, gagasan tentang guru menulis cerita anak juga didasarkan pada pendapat Billy Antoro yang mengatakan bahwa sekolah literat harus mampu menyediakan buku bacaan non-pelajaran dalam jumlah yang besar untuk mengakomodir kebutuhan baca siswa. Ketersedian buku bacaan ini ini menjadi kendala tersendiri bagi sekolah.

Guru menulis cerita, yang kemudian dibukukan, menjadi salah satu solusi untuk menghadapi kendala ketersediaan buku. Kelebihan lain dari guru menulis cerita adalah guru dapat menyesuaikan muatan cerita yang berprinsip pada delapan belas pendidikan karakter sesuai dengan kebutuhan pendidikan anak sekolah dasar.

Kelebihan lain masih berkaitan dengan muatan yang dapat dipilih oleh guru untuk ditulis. Tema sastra anak yang ditulis guru pada program ini dikaitkan dengan konteks lokal daerah Sidoarjo. Hal ini mengacu pada materi pendukung literasi yang dikeluarkan oleh Kementrian Pendidikan dan Kebudayaan bahwa strategi gerakan literasi dapat dilakukan melalui residensial dengan menuangkan pengalaman autentik komunitas/ masyarakat di daerah tersebut melalui tulisan kreatif guna melestarikan nilai budaya dan memperkaya bacaan akan budaya lokal.

Kegiatan pertama dilakukan pada tanggal 27 dan 28 Juli 2019 di Gedung Pimpinan Daerah Muhammadiyah Sidoarjo. Kegiatan ini memuat beberapa materi yakni: 1). Pengertian Literasi dan Literasi Sastra, pada bagian ini dibahas mengenai pengetahuan dasar akan literasi secara umum dan pengetahuan tentang literasi sastra; 2). Pentingnya Literasi Sastra untuk Anak, pada bagian ini dijelaskan tentang PISA, budaya membaca masyrakat Indonesia dan masyarakat dunia, serta keterkaitan kemampuan literasi sastra dengan pendidikan karakter mulia; 3). Memahami Sastra Anak, pada pokok bahasan ini diberikan materi tentang karakteristik dan unsur-unsur sastra anak; 4). Muatan Kearifan Budaya Lokal Sastra Anak, pada topik ini dibahas tentang kondisi geografis dan ciri budaya lokal masyarakat Sidoarjo dengan berfokus pada kondisi alam; dan 5). Menulis 
kreatif Sastra Anak, di mana materi akhir di kegiatan pertama ini mulai dilakukan penulisan draf cerita. Pada sesi ini tim pengabdian bekerjasama dengan narasumber ahli yakni penulis cerita anak untuk memberikan umpan balik terhadap draf tulisan peserta.

Kegiatan kedua dilakukan secara daring dengan membentuk grup whatsapp. Cara ini dipilih berdasarkan pertimbangan efektivitas karena jarak lokasi antar mitra cukup jauh serta kemudahan media sosial tersebut untuk dipakai sebagai wadah berdiskusi secara online.

Kegiatan kedua menghasilkan sembilan sastra anak yang terdiri dari dua cerita gambar dan tujuh cerita pendek. Kesembilan cerita tersebut berjudul: 1). Banjir, 2). Tak Biru Lagi Lautku, 3). GERSANTIK, 4). Rob, 5). Delta Bertahan dari Angin Ribut, 6). Pencemaran Udara di Kampung Asap, 7). Sungaiku Tercemar Bakteri, 8). Rob Tenggelamkan Sekolahku, dan 9). Recycle.

Cerita yang dihasilkan guru tersebut menggunakan konteks budaya lokal dan peristiwa-peristiwa nyata yang pernah ternadi di wilayah geografis Sidoarjo. Dua cerita tentang banjir rob adalah contoh dari peristiwa lokal yang benar-benar pernah terjadi di Sidoarjo. Budaya pesisir (delta) juga tampak melalui cerita "Tak Biru Lagi Lautku" dan "Pencemaran Udara di Kampung Asap". Kedua cerita tersebut mengangkat budaya lokal pesisir yakni budaya nelayan melaut sebagai mata pencaharian dan budaya pengasapan ikan yang berada di sentra industri rumah tangga di daerah pesisir. Konflik cerita dalam cerita-cerita tersebut diselesaikan menggunakan solusi lokal misalnya dengan membersihkan sampah di pinggir laut dan penanaman bakau secara gotong royong.

Kegiatan pendampingan mencatat beberapa permasalah utama yang dihadapi mitra ketika menulis kreatif sastra anak. Pada artikel yang lain, penulis (Martati dan Ari Setyorini, 2018) mencatat beberapa masalah yang biasa ditemui dalam penulisan kreatif cerita anak, yaitu masalah terkait kebahasaan, masalah terkait kesusastraan dan masalah terkait tema dan amanat. Pada kegiatan ini, ditemukan beberapa permasalah dalam tulisan karya mitra. Persoalan kebahasaan ditemukan berupa kesalahan tanda baca, ejaan dan koherensi antar kalimat. Sedangkan persoalan terkait kesusateraan yang ditemui oleh peserta adalah mengenai logika cerita dan alur cerita yang kurang berkembang. Sedangkan unsur tema dan amanat tidak menemui permasalahan yang signifikan karena seluruh peserta mampu memasukkan amanat kearifan lokal khususnya budaya alam pesisir yang menjadi tema cerita.

Kegiatan ini memberikan dampak yang cukup signifikan bagi guru sehingga guru menguasai teknik menulis cerita dan memahami pentingnya literasi sastra. Hal ini dapat dilihat dari penilaian mastery learning peserta. Ketuntasan proyek menulis cerita anak mencatat 9 dari 10 peserta berhasil menyelesaikan proyek mereka, atau sekitar $90 \%$ peserta sukses menyelesaikan proyek menulis sastra anak. Dengan demikian, pelatihan ini dinilai berhasil dilakukan karena 
prosentasi ketuntasan di atas $75 \%$, sebagaimana yang telah ditentukan di awal.

Ketuntasan tidak hanya dilihat dari apakah guru dapat menyelesaikan proyek menulisnya atau tidak, namun juga memperhatikan akan beberapa indikator ketuntantasan pembelajaran penulisan yang diadaptasi dari Nurgiyantoro (2009: 306). Indikator tersebut terdiri dari: 1). Kreativitas pengembangan tulisan, 2). Kelengkapan informasi, 3). Struktur Cerita, dan 4). Penggunaan Bahasa dan Ejaan. Peserta dinilai berhasil menuntaskan proyek jika mereka mendapatkan minimal skor total dari indator penilaian tersebut adalah 75 . Kesembilan peserta tersebut berhasil menulis kreatif sastra anak dengan skor rata-rata 84

Berdasarkan wawancara terhadap mitra, diperoleh keterangan bahwa kegiatan ini memberikan dampak positif bagi mereka. Sebagaimana dijelaskan oleh guru 1 (Peserta 1, 2019) bahwa pelatihan menulis sastra anak memberikan ilmu baru baginya, khususnya mengenai perbedaan sastra anak dengan sastra untuk pembaca dewasa. Menurut dia, pengalaman dan tantangan dalam menulis cerita anak adalah harus menulis dan menggambarkan sebuah hal sesuai dengan perspektif anak dan dengan bahasa yang sederhana sehingga mudah dipahami anak.

Manfaat lain juga diakui oleh peserta 2 (Peserta 2, 2019) bahwa kegiatan ini membuka pemahaman akan pentingnya literasi bagi selain bagi siswa juga bagi guru. Di samping itu, kegiatan ini juga membuat peserta lebih peka terhadap isu-isu yang terjadi di sekitar mereka.

\section{SIMPULAN}

Kegiatan pengabdian lapangan ini mampu meningkatkan pemahaman guru akan pentingnya literasi sastra dan berhasil melatih guru untuk menulis sastra anak sebagai bagian dari gerakan literasi nasional. Kegiatan ini berfokus pada guru sebagai fasilitator dalam proses belajar mengajar di kelas. Hal ini menjadi kelebihan sekaligus kekurangan. Kelebihannya, dengan melatih guru tentang literasi sastra, diharapkan guru dapat mengaplikasi pengetahuan yang diperolehnya di kelas mereka. Namun karena hanya berfokus pada guru, kegiatan ini belum dapat mengetahui apakah terdapat perubahan cara mengajar atau perubahan cara pandang guru tentang literasi sastra apakah ada dampaknya pada proses pembelajaran di kelas.

\section{Ucapan Terimakasih}

Tim pengabdian masyarakat mengucapkan terimakasih kepada DRPM Ditjen Penguatan Risbang Kemenristekdikti yang telah memberikan kepercayaan tim kami untuk melaksanakan Hibah Program Kemitraan Masyarakat Skema Kompetitif Nasional tahun anggaran 2019/ 2020.

\section{DAFTAR PUSTAKA}

Abidin, Zainal. 2007. Analisis Eksistensial. Jakarta: Raja Grafindo.

Antoro, Billy. 2017. Gerakan Literasi Sekolah -Dari Pucuk Hingga 
Akar. Jakarta. Kemendikbud. $<$ diakses dari http://www.indonesiapisacent er.com/2016/12/peringkatdan-capaian-pisaindonesia.html pada 29 November 2019>

Efendi, Muhajir. Mendikbud Melalui Bahasa dan Sastra Kita Bangun Bangsa Indonesia yang Cerdas dan Berkarakter.<diakses dari http://www.kemdikbud.go.idp ada 15 Agustus 2019>

Gold Standard of Project Based Learning Design. <diakses dari https://www.pblworks.org/wh at-is-pbl/gold-standardproject-design >

Martati, B. dan Ari Setyorini. 2018. Pelatihan Penulisan Cerita Pendek Berbasis Multikulturalisme untuk Guru-Guru Sekolah Dasar Muhammdaiyah di Surabaya. JPP IPTEK 3. 1: 4

Mayani, Luh Anik (Ed.). 2017. Materi Pendukung Literasi Budaya dan Kewarganegaraan. Jakarta. Kemendikbud <https://gln.kemdikbud.go.id/ glnsite/wpcontent/uploads/2017/10/cove r-materi-pendukung-literasibudaya-dan-kewargaangabung.pdf>

Nurgiyantoro, Burhan. 2009. Penilaian dalam Pengajaran Bahasa dan Sastra. Yogyakarta: BPFE Yogyakarta.
Peserta 1, Guru. SDM.Program Kemitraan Masyarakat. Wawancara oleh peneliti. Sidoarjo, Indonesia, 28Juli 2019.

Peserta 2, Guru. SDM.Program Kemitraan Masyarakat. Wawancara oleh peneliti. Sidoarjo, Indonesia, 28Juli 2019 